\title{
Forfattere, der har skrevet om Haderslev.
}

\author{
Af Jens Jørgensen. ${ }^{*}$ )
}

Peder Christian Rhode, forfatteren til den i de foregående slægtled yndede folkebog „Samlinger til Haderslev-Amts Beskrivelse", var født i Kolding den 24. dec. 1734. Hans fader var farver $i$ denne by. $I$ en alder af 22 år blev han student fra sin fødebys latinskole, og 1758 tog han attestats (theologisk æmbedsexamen) i København med en dirlig karaktér: non contemnendus (ikke at foragte). Baide som student $0 \mathrm{~g}$ som kandidat underviste han fornemme folks børn i hovedstaden i studeringer, kristendom, tysk og musik, indtil han den 20. jan. 1760 blev kaldet til at være kapellan hos den svagelige sognepræst Jørgen Kastrup til Stepping og Frørup i Haderslev provsti. Han ordinererles til æmbedet d. 13. febr. s. ăr af arkidiakonus Christopher Sass i Haderslev, da generalsuperintendenturen, som havde stiet ubesat siden dr. Reuss' bortrejse $\mathbf{1 7 5 7}$, endnu ikke var tiltrådt af dr.

*) Denne afhandling fremkommer særlig i anledning af, at det iảr - 189.2 - er 600 ảr siden Haderslev fik sin byret. En ligeledes $i$ denne anledning i program for Haderslev Latin- og Realskole for skoleåret 1891-92 offentliggjort afhandling af professor dr. August Sach om „Der Ursprung der Stadt Hadersleben und die Verleihung des Stadtrechts durch Herzog Waldemar IV: im Jahre 1292" forbeholder vi os en senere omtale af.

(Red. anmærkning.) 
Adam Struensee. - I den tid, Rhode opholdt sig her, plejede han på den ene side omgang med de opvakte, på den anden side med forskellige præster i amtet, som kunde meddele ham efterretninger til hans "Samlinger" om byen, amtet $0 \mathrm{~g}$ de præstefamiljer, der sad og tit $\mathrm{i}$ ărhundreder havde siddet $\mathrm{i}$ dets præstegårde. Siledes nærner han i sit skrift hr. Jørgen (Georgius) Boysen i Magstrup og hr. Christian Prætorius i Hammeler, men fremfor alle var arkidiakonus Chr. Sass ham en uultommelig kilde, hvad han selv bemærker i sit skrift (s. 22\%; se Lautrups Chronik s. 55). Hans samlinger udkom imidlertid forst efter hans forflyttelse til Låland. I efteråret $176 \tilde{r}$ blev han nemlig sognepræst til Uttersler, ng d. 5. febr. 1r68 stod hans bryllup med præsteenken Jolianne Dorothea Margrethe Wichmann fra Herredskirke, datter af mag. Jens Kaalund, præst i Tirsted. Først 17r5 udkom amtsbeskrivelsen, trykt i líbenharn. Året efter kom første del af hans „Samlinger til de danske Øers Laalands og Falsters Historie" (anden del udkom først 1794), og samme år blev han provst i Norreherred. Om det sidste skrift hedder det i den Krit. Tilskuer 1r\%6: Dette skrift er af en ligefrem slet smag og opfyldt med lige si̊ urimelige og latterlige ærentyr som beskrivelsen af Haderslev amt. Skønt dette skrift også i mange måder er en besynderlig bog, er den dog ikke så upålidelig, som enkelte, især tyske forfattere, har udpeget den for at være, og man ser også de samme stadigen benytte den. - Den kendes endnu $i$ de fleste egne af Haderslev amt, og nu for nylig har pseudonymen Georg Thomsen ved uddrag af den $i$ "Dannevirke" søgt at oplive mindet om den. Den går her under betegnelsen „£ amtsbeskrivels" og har varet 
en kxy underboldning $o g$ skattet liundskabskilde for de læselystne blandt folket. - Rhode dode d. 11. arg. 1793, hans enke levede derimod i Nakskor til d. 16. juni 1818.

I Wibergs præstehistorie, hvor man finder de fleste oplysninger om ham, beskrives han som en hoj, mager mand, sirlig og bleg, men smuk, og altid pynteligt klædt. Desuden var han meget snaksom.

Adolph Rudolph von Brincken er fodt den 24. juli 1754 i Hatsted i Husum amt, hror hans fader Melchior Christoph v. B., en indrandret brunsviger, var diakonus $(\dagger 1 \%(62)$. 1782 blev han rektor i Wilster og fire år efter rektor i Hadersler. 1 r99 blev han kaldet til præst i Vonsbæk og tiltrialte æmberlet 1800, men allerede 1808 d. 21. sept. døde han.

I modsætning til den foregaende forfatter med sit anselige skrift, har denne kun leveret lidet, og det deraf, som nu har det storste værd, var han endda kum indsender af. Som rektor i Haderslev folte han trykket af bide latinskolens og byens dálige finansforhold, og han sogte, bl. a. ved ivrig undersggelse af dokumenter, henhorende til latinskolen, at bringe klarhed til reje $i$ dens finanstilstand. Herred fremkom den rækle „Aktenstücke, die lateinische Schule in Hatlersleben betreffend", som findes i nogle årgange af Schl.-Holst. Provinzialberichte (1787-98), hroraf en del er aftrykte efter Rhodes amtsbeskrivelse, - og „Beiträge zur Geschichte der kgl. Lateinsch. in Hadersl." (1\%9(9). Men det rardifuldeste, en fremtidsplan for byens læreanstalt findes $\mathrm{i}$ et (ristnok fingeret) brev til ham fra $\mathrm{C}-$, som han lod indrykke i Prov. Ber. 1\%91 under overskriften: ,Etwas über die Stadt Hadersl. 
in Rücksicht einer daselbst zu gründenden höhern Schulanstalt", hvori det bl. a. hedder (i oversættelse): Her ligger for mig kårtet over Jylland, Slesvig og Holsten. Jeg spørger: Var det ikke nødvendigt, og vilde det ikke være meget nyttigt at anlægge en højere undervisningsanstalt end de nuværende skoler $\mathrm{i}$ dette store og rige stykke land "“" - At Haderslev er det mest passende sted, piviser han så: „Denne by ligger midt imellem Nørrejylland og hertugdømmerne. Begge sprog, dansk og tysk, tales med lige stor fuldkommenhed af indbyggerne. Luften er ualmindelig sund, egnen behagelig. Ynglingen (fra det 14. år) fra Jylland har ikke længere end han fra hertugdømmerne, når han skal fortsætte og tremme sine studier i denne skole, såledtes som jeg vil danne den, før hans indtræulelse på den sidste høje skole. Hverken en larmende handel eller en talrig garnison eller glimrende hoflystigheders ødsie pragt kan her være de blite og stille muser til hinder. Endnu en gang gentager jeg: De næunte byer (han har i det foregående næunt latinskolerne) har deres skoler. Men at undersqge, med hvilke mangler enhver af dem har havt at stride indtil denne dag, er her ikke stedet til. Man kan blot læse efter i Ehlers' skrifter, i Prov. Ber. og fortjente skolemænds bitre klager over disse skolers almindelige fordærvelse, i hvert tilfælde ogsi̊ se lidt selv og tænke på det, så vil man uden forstørrelsesglas opdage meget, som skulde forbedres. - - - Kærligheden til fædrelandet vil med hvert år blive stærkere, og samlivet af unge mennesker fra hertugdømmerne med ynglinge fra riget vilde frembringe uendelig nytte $\mathrm{i}$ henseende til den sympatetiske, moralske o $g$ selskabelige omgang, som endnu er noget tilbageholdende, fremmed og 
kold mellem fødte danske og provinsboere." - Særlig tanken om samlivet mellem dansktalende og tysktalende står for v. Brincken som den herligste frugt af en sidlan højere skole. I sin svarskrivelse til forslagstilleren siger han (Prov. Ber. 1791, IV, 45-49): - „Blandt de mangfoldige fordele, der kan ventes af den af Dem projekterede læreanstalt, vilde en af de nyttigste og værdifuldeste vel først og fremmest være den danske og tyske ungdoms gemytters nojere forening i karlighed og velvilje. Hvor uvillige, desværre! står ikke begge partier endnu overfor hinanden! - - Danskernes store mængde skælder som bevis på dens råhed tyskerne ud for "hunde", som forhen de stolte jøder tillagde herlningerne denne pæne titel. Tyskeren - det forstar sig: 'den mindre dannede - taler om „dumme Dänen “, og tror, at hans ældre kultur alene giver ham forrang for hin - og sætter sig derved omtrent i samme forhold til sine danske brødre, som hans frankiske brødre mener at sti i til ham." At dette arveonde ikke kan modarbejdes bedre end red den foreslåede hojere skole, udvikler han nærmere (s. 47): „Thi den ny vordende skole vil for det forste få lærere fra begge kongelige lande. Tyske og danske vil blive ansatte ved den i lige antal efter deres brugbarhed. $\mathrm{Og}$ hvor meget vilde ikke allerede derved de „forskelligtungede" folks gemytter nærme sig hinanden! Ved lærernes omgang vilde grunden lægges til en udsoning, som man kuncle have ventet af universitetslærernes samliv i residensen, men som i følge erfaringen ikke er at nå ad den vej. Hvorledes kunde det vel også være anderledes, når det ene parti af lærerne kun er det talte, således som det er i Kabenhavn? Når de skal fornægte deres moders- 
mål, tvinge deres undervisning ind $\mathrm{i}$ et fremmed sprogs klædebon og aflægge deres originalitet for at blive copier efter et herskende partis sind og forgodtbefindende? Her, ved vor af Dem foreslåede læreanstalt, skulde enhver lærer vedblive at være, hrad han efter sin herkomst er. Han skulde ikke pålægge sig tvang i nogen som helst henseende. De samme rettigheder, de samme fortrin, den samme virksomhed vilde ophære den usalige spaltning, der vil vedblive så længe mellem danske og tyske, som læererne ikke agtes for personlige fortrins skyld, men på grund af deres nationale karakter. Selr i det sjældne tilfælde, at lærerne ikke havde det mindste kendskab til hinandens modersmål, kunde de let og uden møje lære af hverandre $0 \mathrm{~g}$ i byens gode selskab så meget dansk $0 \mathrm{~g}$ tysk, som der vilde kræves til at conversere. Undervisningen skulde gires i begge sprog, studiet af den danske og tyske litteratur og af sprogene, hrormed den samlede ungdom skulde sysselsætte sig, vilde gensidig tilintetgøre nationernes fordomme; man lærte at kende, agte og elske hinanden, at vinde tiltro til hinanden og villig at give den forrangen, til hrem fortjenestens tungere rægtskål bøjer sig hen. - Her skulde man med rarme og eftertryk prædike om, hvor samfundsfjendtlig denne last (nationalhadet) er i sine følger, og hrorledes vi derved vil blive forrædere mod statens vel og ror privat-lyksalighed. Strafværdigheden hos sådanne forfattere ${ }^{*}$ ), som ret med flid søge at nære og forstorre dette arreonde, skulde man

*) Således som f. ex. den ellers fortræffelige og for sin frimodigheds skyld ærværdige forf. til det periodiske skrift: Rixdaler Sedlens Hændelser. [P. A. Hejberg].

Forf. anmærkn. 
fremstille mandigt og kækt, og derved rustede man eleverne til at rogte sig for denne forbrydelse.

En slægt vilde have indflydelse på ren anden, meddele den sit sindelag - dette vilde gia fra forældrene over på bornene og $\mathrm{i}$ den anden generation vilde tyske provinsialer og danske omfavne hinanden som gode sønner og døtre af én fader! Alene denne hjærteopløftende fordel vilde være den ønskerle plantehave værd."

Fra sysselen med latinskolens dirrlige forfatning og planen til den højere anstalt på dennes ruiner, kommer han opmuntret ved Rhodes exempel ind på tanken om at forfatte en topografi over Hadeisiev, vistnok til Prov. Berichte, hvis opfordringer i disse ir til sine læsere om at give sadlanne over de enkelte byer og sogne, ret godt blev efterkomne. $1793 \mathrm{kom}$ så hans „Vorerinnerung wegen einer Topographie der Stadt Hadersl.“, hvis største nyhed er omtalen af „det ædle broderpar Frederik II. og Johann den ældre"; mens Rhode i en „Ergänzung" (Prov. Ber. 1793, II, 169) får det skudsmål, at „hans skrift er affattet uden historisk kritik, men dog med frimodighed."

Topografien kom aldrig, skønt viljen var god, men derimod indsendte han et brev, han havde fäet fra en unævnt haderslevsk borger til svar på et lille stykke, som Prov. Ber. havde optaget af "Oederiana": Warum setzt der Haderslebener Landmann seine Waaren lieber in der Ferne als in der Nähe ab? ( $\mathrm{l}$ 'g. 1792, V, 181) og dette sporgsmål med dets besvarelse tilligemed brevvexlingen om den højere læreanstalt giver et godt skilderi af den gode by Haderslev for 100 år siden. Dette er det bedste bidrag, v. Brincken har givet til Haderslev bys historie, 
hvorfor det senere vil følge i oversættelse. Det findes i Prov. Ber. 1793 II s. $145-154$.

Med hans forflyttelse til Vonsbæk præstegård hører hans forfatterskab op.

Erasmus Lautrup, Haderslev bys egenlige krønikeskriver, rar en søn af Johan Christian Lautrup, præst i Åstrup fra 17r0- r5, død 1803 d. 4. dec. som præst i Tyrstrup; han var gift med arkidiakonus Chxistopher Sass' datter fra Haderslev. Sømnen Erasmus blev født i Tyrstrup d. 15. Marts $1782 \mathrm{og}$ han besøgte vist Hadersler latinskole. 1806 blev han indskieren som student red Københavns universitet, hror han (ligesom faderen) tog attestats d. 13. jan. 1807 med 2. karakter. Allerede 1808 i argust blev han kaldet til diakonus i Haderslev (kgl. stadfæstelse d. 1.9. sept.) og d. 6. april 1809 tillige hospitalspræst. Han havde aldrig andre end disse ambeder. Den 25. arg. 1848 blev han afskediget (ikke, som Barfod i Danm. Gejstlighed mener, af den slesr.-holst. reg.) og døde d. 12. sept. 185\%. Hans ægtefælle Sophie Charlotte von Voss, hvis fader var oprartende kavaller hos landgreven af Hessen, døde d. 9. juli 1851.

Pastor Lautrup var en begavet mand med digterisk ærne og en let, ofte bidende skarp pen. Han har aldrig udgivet prædikener og har vist slet ikke tænkt på det, skønt han efterlod sig en mængde i håndskrift. I modsætning til sine forfædre, præsterne Sass i Haderslev, der både har ladet danske prædikener trykke og skrevet danske rers, ja endog hærdet brugen af det danske sprog (se Lautrups Chronik s. 52 og Rhode s. 224), var Lautrup egenlig udelukkende tysk forfatter, skønt dansk præst. 
I en ung alder bler han præst, $o$ g hadersleverne strømmede til kirke for at høre den unge prrsts interessante prædikener, hrori der ikke var så lidt almen fattelig filosofi, iklædt et blomstrende sprog. Hans theologiske anskuelser finder vist deres korteste udtryk i et lille stykke i „Lyna“ (1838, 14. oct.) med overskriften Troens og Lydighedens Avtoritet. En tro, der ikke undersøges, er blind, en lydighed, som er ubetinget, er slavisk. „Selv guddommen kan ikke kræve en ubetinget avtoritet, da den så vilde fratage mennesket det, der gør ham til menneske, nemlig hans fornuft af hans frihed, som den selv har givet ham - eller $\mathrm{i}$ det mindste forbyde ham at bruge den." Som alle „religionslærere" fra den tid interesserede han sig stærkt for almenrel og borgerdyd (i afholdssagens interesse hilste han ølbrygger Nielsens ny $ø$ l med et stykke $\mathrm{i}$ „Lyna“), og hans første skrift handler også om veldædighedsanstalterne i Haderslev (1831). Lautrup var også en liberal mand, derfor var han selvskreven som medarbejder red „Lrna“, hris redaktion han i 1838 overtog. I denne årgang findes satiriske digte af ham, små interessante artikler mod de herskende fordomme, men også længere artikler om slesrigernes sprogpetition og "Lrnas" ny konkurrent „Damnevirke“. Snart digter han om Censuren (Lyna 1838, nr. 2). Snart driver han spot med forbudene mod talefrihed, i det han foreslåer at oprette en tænker-club, hror alle medilemmer ved indmeldelsen får en mundkurr på, og i første møde skal det spørgsmål behandles, om det overhovedet er tilladt at tænke. Eller han skriver en sang til et borgergilde, hrori hvert andet vers, tit hver anden linie, er på dansk, hver anden på tysk (seks vers): „Den bedste for- 
ligelsescommissair, To parter i strid at forene, $\mathrm{Er}$ loctor Bacchus, det ved enhver, Han konsten forstår alene, :: : At sammensmelte servil, liberal, Når han har fylät en glædespocal.::

Sådan en sang er lige si̊ betegnende for hans standpunkt, virksomhed og arbejdsmåde, som de små uskyldige strøbemærkninger, der titter frem hist $0 \mathrm{~g}$ her $\mathrm{i}$ hans monographi om Haderslev, f. ex.: „Den ulyksalige sprogstrid“, „de nymodens navneforandringer, aldeles vilkårligt, som Åbenrå for Apenrade, Danske skov for Dänisch Wohld “, „at ville stanse udviklingens naturlige gang“ (mens dansken sover, lægger tysken sig henover) o. s. v. - Dette hans hovedskrift udkom 1844. Det er væsenlig bygget på de samme kilder som Rhodes amtsbeskrivelse, nemlig på de Sassiske manuscripter, som ved skødesløshed gik til grunde i Garding efter ejerens G. A. Sass' død 1826. Men Lautrup havde i tidens løb gjort mange uddrag af dem (Chronik s. 56). Om end den historiske indledning ikke kan bestå for den moderne forsknings kritik, så er efterretningerne om Haderslev i det 16. arhundrede, om gejstligheden, især slægten, og de øvrige personal-historiske efterretninger pålidelige og værdifulde, så meget mere som byens gamle kirkebøger gik til grunde ved branden 1759 . Det samme må man sige om efterretningerne fra hans egen tidsalder, hvor dog måske kun den ene side af sagen ses. Lige si̊ lidt her som i "Lyna" er han kedelig at læse. Lautrup var også en stor børneven. For det meste gik han med godter i lommerne til de små, men han gjorde ogsi̊ større ting for dem. For at bøde på den daværende skoles tarvelighed, underviste .han selv sine børn - tre døtre - i sprog og andre "skonne viden- 
skaber". Også døtrene fía hans omgangskreds deltog i disse timer, hvoriblandt de litteraturhistoriske timer med oplæsning og deklamatoriske wvelser var særligt tiltrækkende for de unge piger. Saledes var Lautrups interesser mangesidige som hans begavelse, den han brugte for at fremme det almennyttige, men altid som tysker. Man ser, hvor stark udviklingen i den retning er gået frem siden den foregående forfatters tid. Arsagen til hans pensionering i 1848 var et slagtiltælle, som dog atter fortog sig. Med sundheden vionnede atter virkelysten, han beklagede mangelen på arbejde, men måske blev lidt undervisning den eneste afbrydelse i hans stille liv. Han er jordet på den skont liggende klosterkirkegård, hvor P. Hj. Lorenzens grav ogsi er, og hror gravminderne med deres fortidsformer og mest tyske indskrifter afspejler den tids haderslevske patriciere, hvis støv de dækker, idet de stadfæste Lautrups udsagn: Tysk var intelligensens sprog.

Georg Fiedrich Claussen var søn af justitsråd Ernst Julius Cl., der fra Toftlund blev forflyttet til Haderslev som herredsfoged i Tyrstrup herred, og Sophie Christine Charlotte, f. Langreuter. G. F. Claussen blev fortt i Toftlund d. 31. jan. 1806. Tidligt kom han hjemmefra for at gå i Haderslev latinskole, i hvilke år han var $\mathrm{i}$ sin morfaders justitsråd og herredsfoged Langreuter's hus. Som student lagde han sig efter jura på universiteterne i Kiel og Heidelberg i irene 1825-28; i førstnæunte by var A. W. Cramer, N. Falck og Thib aut især hans lærere. 1829 fik han æmbede, i det han blev cancellisekretær ved overretten på Gottorp, en stilling, han beklædte indtil 1850 . 
Som cancellisekretær Clausen er han velbekendt fra stændertiden - 1838 valgtes han som deputeret for Åbemri, senere for Haderslev (suppleant) - og for dem, der har lest L. Skaus fortrinlige arbejde om Peter Hjort Lorenzen. I disse år falder også hans betydeligste offenlige virksomhed, da han først sammen med sin ungdomsven P. H. Lorenzen og grev Moltke stod som leder af det lille demokratisk-liberale parti i den slesvigske stænderforsamling, $o g$ siden som en hertugeligsindet slesvigholstener. Disse tre mænd var de dygtigste $o g$ betydeligste blandt de liberale, og hertil kom endnu for Claussens redkommende, at han ved sin æmbedsstilling, som gav ham adgang til regeringens og overrettens arkiver og ved en sjælden fortrolighed med de skriftlige sagers behandling kom til at stå som en værdifuld partifælle. "Claussen var et slags lexikon for den liberale fraktion, og han var som oftest $i$ stand til at lose de for alle dunkle gåder, både $i$ administrationen og retsplejen, " siger L. Skau i nærnte skrift (s. 42). Claussen og P. Hj. Lorenzen, som i de to første stænderforsamlinger boede hos ham i Slesvig, stemmede godt overens i deres constitutionelle ønsker og afgjorte uvilje mod hertugen og prinsen. Da de øvrige liberale venner, Heiberg, Reiche, litterat Hansen, vilde have deres folkeskrifter udelukkende skrevne på tysk, var Lorenzen og Claussen ligeledes enige om, at dansk også skulde bruges. Claussen brugte sin pen flittig. Utrættelig sendte han så vel som de næunte liberale, især Heiberg, Reiche og Hjort Lorenzen bidrag til de små frisindede slesvigholstenske blade, og dr. Heibergs SchleswigHolsteinische Blätter var Heiberg og Claussen vel næsten 
ene om både at skrive og læse. Og hvor vigtigt et bidrag til tidens historie har han ikke ydet red de mangfoldige breve til P. Hj. Lorenzen gennem flere år. Det er også ham, der kom efter, at de artikler mod P. H. L., som stadigt kom til syne i "Itzehoer Wochenblatt", gik fra hertugen gennem en person B. Lüders i Slesvig til dette og andre blade (nærnte skr. s. 104.) I et andet brev underretter han sin ren om den irettesættelse, han havde fảet for sin politiske virksomhed. Først modtog Cl. en næse, fordi han havde underskrevet adressen til de syv Gøttingske professorer, der for deres protest mod kongen af Hannovers omstyrtning af forfatningen havde fået deres afsked i unåde. Men samme efterår (1838), efter hans valg i Åbenrå, holdt han skåltaler, der sammen med en beskrivelse af festlighederne blev gengivne af et åbenmundet hamborgsk blad. Både Claussen og overretten mitte afgire erklæring om det forefaldne, og kort før jul måtte han fremstille sig for den forsamlede overret for $\mathrm{i}$ „kongens navn" at modtage en irettesættelse med trusel om at blive afsat, hvis sligt gentoges. Men med Lorenzens frontforandring hører denne kilde op. Da denne stod frem pai de danske slesvigeres regne, gik Claussen over til hertugens parti. I folge hans breve truedes de liberale af farer både fra danskheden i Nordslesvig, fra nyholstenerne, som ikke vilde noget Slesvigholsten, og fra aristokratiet med hertugen i spidsen. Men da Cl. hverken vilde være nyholstener eller dansker, og de liberale $\mathrm{i}$ P. Hj. Lorenzen harde mistet deres bedste mand, stod tilslutningen til hertugen, hror hårdt det end maitte falde, rel som den eneste udvej.

I de følgende år findes $\mathrm{Cl}$. ikke blandt de mest talende 
i stænderforsamlingen. Han indbringer forslag både angående chausseer og stempelpapir, forlig ved voldgiftsmænd, og så fremdeles, men også om at afværge danskernes indblanding i hertugdømmets anliggender og tager del i debatten om Slesvigs indlemmelse i det tyske forbund. Ved den lejlighed siger han bl. a. følgende (Stændert. 1846 sp. 377-78): „Jeg indrømmer gærne de foregående talere, at hvis man i de enkelte valgdistrikter vilde forespørge hos vælgerne, om de var stemte for hertugdømmet Slesvigs optagelse i det tyske forbund, vilde dette af den største part besvares med nej; men jeg tror ligesá lidt, at de er i stand til at argumentere nogen særdeles modbydelighed derfor. Det går hermed, som med alle spørosmål i den højere politik: de ligger udenfor deres bedømmelses sfire. "

Da den slesvigske overret i 1850 blev ophævet, modtog Claussen sin afsked uden pension; han rejste med sin familie til Lybæk, hvor han 1853 tik et lille æmbede som sekretær ved handelskammeret. I sive yngre dage havde han vist delt de øvrige liberales beundring for den norske konstitution; i Lybæk kom han atter under norsk indflydelse, men fra en anden side. Historikeren P. A. Munchs indvandringstheorier (Norske Folks Historie $\mathrm{I}_{\text {r }}$ 1. og 2. afsn.), hvis fremkomst vakte si̊ stor opsigt, fandt hos Claussen afgjort tilslutning; han oversatte dele af de første afsnit af dennes historie, og Munchs indtlydelsepræger hans længe efter udgivne skrift: Beiträge zur Geschichte u. Beschreibung von Hadersl. u. Umgegend, som udkom i Haderslev 1877. 1864 kom han nemlig til Haderlev som thingskriver (aktuar) for Gram herred, $186 \%$ blev han amtsdommer, men ved den ny prøjsiske justitsorganisation 1869 pensioneret, og fra nu af indtil sin død: 
syslede han med historiske studier, især redrorende Haderslev. Om end Claussens slutninger fra den forhistoriske tid og fra historiens dæmring må stå og falde med $\mathrm{Munchs}$ theorier, som rist nu helt er opgirne af fagmænd, kan dog ingen uden stor interesse læse hans fremstilling særlig af Haderslevs udseende og nærmeste omgivelser fra den tid, da ri må sarne enhrer noget fyldigere efterretning. Han har ogsit forudsætninger, som at Slesrig og Holsten har samme nationalitet, eller at kobstadvæsenet i Sønderjylland er tysk ${ }^{*}$ ), som er fejlagtige, og tilslutningen til det projsiske herrellomme og Bismarck mærker vel ogsi bogen, men for de sidste trende århundreder yder skififtet vist pålidelige efterretninger om byens retsræsen $0 \mathrm{~g}$ lign., da forf. her hele tiden har stottet sig til dokmmenter, først $o g$ fremmest til de i skriftet (side 111) omtalte von Neuhoeffelske samlinger - som efter hans død befinder sig i rådstuearkivet i Haderslev - $0 \mathrm{~g}$ dernæst dette arkirs indhold, som han i de senere år ordnede. Om hans flid og granskninger til det sidste, bærer hans efterladte skriftlige optegnelser og forbedringer til „Beiträge" vidne. Den værdifuldeste del af hans store bogsamling havde han testamenteret latinskolens bibliothek.

Han dode i Hadersler d. 30. now. 1890, men blev jordet i Lybæk ved siden af sin forlængst afdode ægtefælle Catharine Langheim fra Hadersler, datter af Slots- eller Hjorteapothekets ejer.

*) Se prof. C. Paulsens afhdl. „Beitrag z. Geschichte der südjütischen Stadtrechte" i Falcks Staatsb. Mag. 1826. 